\title{
Bruk av omega-3-fettsyrer i forebygging av hjertesykdom
}

\author{
Sammendrag \\ Bakgrunn. En rekke studier viser at \\ inntak av fet fisk eller omega-3-fett- \\ syretilskudd tilsvarende to fiskemål- \\ tider i uken reduserer risikoen for \\ hjertesykdom. Hensikten med denne \\ artikkelen er å gi en oppdatert oversikt \\ over emnet og å konkretisere anbefa- \\ linger vedrørende bruk av omega-3- \\ fettsyrer.
}

\begin{abstract}
Materiale og metode. Artikkelen er basert på ikke-systematiske litteratursøk i databasene Medline, ScienceDirect og Embase og egne erfaringer med pasienter.
\end{abstract}

Resultat. I primærprevensjon anbefales det fet fisk som kilde til omega-3fettsyrer. Mengden bør tilsvare omkring 0,5-1 g av fettsyrene EPA/ DHA daglig. I sekundærprevensjon er anbefalt dose omkring $1 \mathrm{~g}$ daglig via kostholdet, eventuelt supplert med tilskudd ved behov. Reseptpliktige omega-3-fettsyrer (Omacor) har indikasjon ved sekundærprofylakse etter hjerteinfarkt. Dosen er én kapsel, tilsvarende 840 mg EPA/DHA daglig. Resultatene fra den nylig publiserte GISSI-HF-studien viste moderat reduksjon i totaldødeligheten hos pasienter med hjertesvikt ved bruk av Omacor.

Fortolkning. Nyere resultater styrker grunnlaget for å vurdere bruk av omega-3-fettsyrer i forebygging av hjertesykdom og ved hjertesvikt. Det trengs mer forskning angående doseringen og for å avdekke i hvilken grad disse fettsyrene forebygger arytmier og plutselig hjertedød. Det er nødvendig med studier som avklarer om den triglyseridsenkende effekten av høye doser omega-3-fettsyrer gir mindre hjertesykdom hos pasienter som statinbehandles.

\author{
Asgeir Græsdal \\ asg3@hotmail.com \\ Lipidklinikken \\ Medisinsk avdeling \\ Oslo universitetssykehus, Rikshospitalet \\ Sognsvannsveien 20 \\ 0027 Oslo
}

Observasjonelle og randomiserte studier har dokumentert positive kardiovaskulære effekter av omega-3-fettsyrer brukt i primærog sekundærprofylakse av hjertesykdom (1-9). Mekanismen bak disse effektene og konsekvensene for terapeutiske anbefalinger har vært omdiskutert. Hensikten med denne artikkelen er å gi en oppdatert oversikt over bruken av omega-3-fettsyrer i forebygging av hjertesykdom og å konkretisere terapeutiske anbefalinger til ulike pasientgrupper.

\section{Materiale og metode}

Artikkelen er basert på ikke-systematisk litteratursøk i databasene Medline, ScienceDirect og Embase samt egen klinisk erfaring i behandling og forebygging av hjerte- og karsykdom.

\section{Struktur og funksjon}

Flerumettede fettsyrer finnes i form av omega-3-fettsyrer og omega-6-fettsyrer. De langkjedede omega-3-fettsyrene med 20 eller flere karbonatomer har marint opphav. De viktigste er dokosaheksaensyre (DHA; C22:6n-3) og eikosapentaensyre (EPA; C20:5n-3). Det første tallet angir antall karbonatomer, det andre antall karbon-karbondobbeltbindinger og det siste angir posisjonen av forste dobbeltbinding fra den n-terminale (omega) enden av molekylet (10).

Alfalinolensyre (ALA; C18:3n-3) og omega-6-fettsyrene syntetiseres av planter. Kilder til alfalinolensyre er planteoljer og en del grønnsaker, og fettsyren kan kun i begrenset grad omdannes til EPA og DHA i menneskekroppen $(8,9)$. Omega-6-fettsyrene finnes $\mathrm{i}$ store mengder $\mathrm{i}$ fullkorn og vegetabilske oljer. Den humane organismen mangler enzymer som er nødvendig for å innføre en omega-3- eller omega-6-binding. Omega-3- og omega-6-fettsyrene er derfor essensielle og må inntas via kostholdet (10).

Aterosklerotisk plakk består av en nekrotisk lipidkjerne med rikelige mengder inflammatoriske celler omgitt av en fibrøs kappe. Ustabile plakk har en stor nekrotisk kjerne, og den fibrøse kappen er tynnere enn hos stabile plakk $(8,9,11)$. Akutt koronarsyndrom skyldes vanligvis ruptur av det aterosklerotiske plakket - med påfølgende aktivering av hemostasesystemet, trombedanning, iskemisk muskelskade og eventuelt arytmi $(8,12)$. Plakkets størrelse og stabilitet avhenger av en rekke faktorer. Hos personer med homozygot familiær hyperkolesterolemi, som er født med kolesterolnivåer i størrelsesorden 15-25 mmol/l, anses kolesterol som en tilstrekkelig årsak til plakkdanning. Disse pasientene făr hjerte- og karsykdom allerede som barn hvis de ikke behandles med kolesterolsenkende medikamenter og LDL-aferese (13). Motsatt medfører mutasjoner som gir reduksjon i LDLkolesterolnivået betydelig redusert risiko for å utvikle aterosklerotisk hjertesykdom $(14,15)$.

Omega-3-fettsyrenes funksjon er et resultat av deres struktur og virkemåte ved vaskulære patologiske tilstander. Inkorporering av disse fettsyrene i cellemembranen gir økt fluiditet og permeabilitet og innebærer gunstige elektrofysiologiske effekter $(9,16)$. Fettsyrenes interaksjon med cellekjernen gir redusert triglyseridsyntese i leveren (17). Mekanismen her antas dels å være aktivering av kjernereseptoren peroksisomproliferatoraktivert reseptor- $\alpha$ (PPAR- $\alpha$ ), som stimulerer betaoksidasjon av fettsyrer (17). Omega-3-fettsyrer er substrat for danning av prostaglandiner, tromboksaner og leukotriener, som inngår i reguleringen av inflammasjon, plateaggregasjon og endotelets funksjon $(8,9,16)$.

Fettsyrenes gunstige virkninger knyttes på denne bakgrunn til antitrombotiske, antiinflammatoriske og antiarytmiske effekter samt bedret plakkstabilitet, endotelfunksjon og lipidprofil. I enkelte studier er det vist proinflammatorisk virkning med økte nivåer

\section{Hovedbudskap}

- Studier har vist at omega-3-fettsyrer har effekt i forebygging av hjertesykdom

- De fleste kan oppnå tilstrekkelige nivåer av omega-3-fettsyrer ved riktig kosthold

- Det trengs mer forskning for å avklare optimal dosering og hvilke befolkningsgrupper som har behov for tilskudd av omega-3-fettsyrer 


\section{Ramme 1}

\section{American Heart Associations anbefalinger for inntak \\ av omega-3-fettsyrer (7)}

Primærprofylakse: Inntak av fet fisk minst to ganger i uken. I tillegg anbefales føde rik på alfalinolensyre

Etablert hjertesykdom: Omkring $1 \mathrm{~g}$ EPA + DHA daglig, fortrinnsvis fra fet fisk. Eventuelt supplement i samråd med lege

Alvorlig hypertriglyseridemi: $2-4 \mathrm{~g}$ EPA + DHA daglig i form av kapsler

av endoteliale adesjonsmolekyler og cytokiner ved bruk av høye doser konsentrert omega-3-fettsyretilskudd. Disse effektene antas å skyldes peroksidasjon av de flerumettede fettsyrene (10)

\section{Studier med omega-3-fettsyrer}

Observasjonelle studier

I mer enn 15 prospektive kohortstudier, som omfattet personer både med og uten kjent hjertesykdom, har man undersøkt sammenhengen mellom omega-3-fettsyreinntak og kardiovaskulær død (6). Ifølge disse studiene har de som inntar omega-3-fettsyrer i størrelsesorden 250-500 mg daglig, 25-50\% mindre risiko for å dø av hjertesykdom enn de med ubetydelig forbruk $(6,18)$.

Det er fra tidligere dokumentert svært lav forekomst av hjertesykdom og aterosklerose i Japan, til tross for at risikofaktorer som røyking og diabetes er minst like utbredt der som i vestlige land $(2,19-21)$. I en ny studie har man sammenliknet forekomsten av aterosklerose hos japanske menn i Japan, japanske menn som hadde flyttet til USA og hvite menn i USA (20). Japanske menn i Japan hadde lavest forekomst av aterosklerose, mens hvite menn og japanere i USA hadde like høyt nivå. Det ble funnet en invers relasjon mellom omega-3-fettsyrenivået i serum og intima-media-tykkelsen på carotisarteriene og grad av kalsifisering av koronararteriene. Det konkluderes med at svært høye nivåer av omega-3-fettsyrer i Japan, på grunn av et betydelig inntak av fisk, har antiaterogene effekter som er uavhengige av tradisjonelle kardiovaskulære risikofaktorer (21).

\section{Randomiserte studier}

Fire av seks store randomiserte studier med totalt mer enn 40000 deltakere har vist reduksjon i kardiovaskulære hendelser ved bruk av omega-3-fettsyrer. I GISSI-studien (Gruppo Italiano per lo Studio della sopravvivenza nell'Infarto Miocardio) fra 1999 ble 11324 pasienter med gjennomgått hjerteinfarkt randomisert til én kapsel med EPA/ DHA (850 mg), vitamin E eller placebo. For
$12,3 \% \mathrm{i}$ intervensjonsgruppen og 14,6\% i kontrollgruppen inntraff det primære endepunkt, som var død, ikke-fatalt hjerteinfarkt og hjerneslag. Dette gir en statistisk signifikant reduksjon i relativ risiko på $15 \%$ hos dem som ble randomisert til EPA/DHA $(\mathrm{p}=0,023)$. Henholdsvis $1,9 \%$ i omega-3fettsyregruppen og 3,9\% i kontrollgruppen døde plutselig. Det vil si en statistisk signifikant reduksjon i relativ risiko for plutselig død på $45 \%$ i omega-3-gruppen. Studien var ikke blindet (1).

I JELIS-studien ble 18645 japanske pasienter randomisert til 1,8 g EPA i tillegg til statinbehandling eller til placebo og statinbehandling. Etter 4,6 år ble det primære endepunktet påvist hos 2,8\% i EPA-gruppen og hos 3,5\% i kontrollgruppen $(\mathrm{p}=0,011)$. Dette gir en reduksjon i relativ risiko på $19 \%$ for det primære endepunktet, som omfattet plutselig død, fatalt og ikke-fatalt hjerteinfarkt, ustabil angina og koronar intervensjon. Hovedgevinsten lå i reduksjon i forekomsten av ustabil angina og ikke-fatale koronare hendelser i EPA-gruppen (21).

DART-studien (Diet and Reinfarction trial) omfattet 2033 menn med tidligere hjerteinfarkt. Totaldødeligheten etter to år ble statistisk signifikant redusert med $29 \%$ hos dem som fikk råd om bruk av omega-3fettsyrer i forhold til dem som fikk råd om $ø k t$ fiberinntak eller redusert inntak av mettet fett - dødeligheten i de tre gruppene var henholdsvis $9,3 \%, 12,1 \%$ og $10,9 \%$ (4).

I den nylig publiserte GISSI-HF-studien ble 7000 pasienter med hjertesvikt i NYHA-klasse II-IV randomisert til $1 \mathrm{~g}$ omega-3-fettsyrer eller placebo. 955 (27\%) i omega-3-fettsyregruppen døde og 1014 (29\%) i placebogruppen. Dette gir en reduksjon i relativ risiko for død på $9 \%$ etter fire års bruk av omega-3-fettsyrer $(p=0,04)$. Kardiovaskulær mortalitet eller innleggelser av kardiovaskulære årsaker var også sjeldnere $\mathrm{i}$ intervensjonsgruppen enn $\mathrm{i}$ kontrollgruppen $(57 \% \operatorname{mot} 59 \%, p=0,009)$. Det antall som måtte behandles for å unngå ett dødsfall i studieperioden var 56 (22).

I en randomisert studie hvor 3114 menn med angina ble fulgt i ni år, fant man ikke effekt av økt fiskeinntak eller fiskeoljetilskudd (23). Svakheter med studien var at kun $50 \%$ av pasientene hadde dokumentert koronar hjertesykdom og at kostveiledning kun ble gitt ved studiestart og etter ni måneder. Det amerikanske helsedepartementet har konkludert med at studien er metodologisk svak (24).

På American College of Cardiologys kongress i 2009 ble resultatet fra OMEGA-studien presentert. 3827 pasienter ble randomisert til en kapsel Omacor eller placebo 3-14 dager etter gjennomgått hjerteinfarkt. Primært endepunkt var plutselig hjertedød $i$ løpet av 12 måneder. Det ble ikke påvist signifikante forskjeller mellom gruppene. Dødeligheten var betydelig mindre enn man hadde regnet med, og studien hadde derfor for liten statistisk styrke til å vise noen effekt (25).

\section{Eksperimentelle studier}

En randomisert norsk studie med 563 menn viste effekt på karstivhet, men ikke på intimamedia-tykkelse av a. carotis ved bruk av 2,4 g EPA/DHA daglig i tre år (26). Data fra Framingham-undersøkelsen viste at det var en sammenheng mellom hvilepuls og plutselig hjertedød (27). I en studie førte inntak av 810 mg daglig av EPA og DHA til en reduksjon i hjertefrekvensen fra 74 til 69 slag i minuttet (28). En metaanalyse basert på randomiserte studier har vist liknende effekter (29). I dyremodeller har omega-3-fettsyrer redusert forekomsten av fatale arytmier $(30,31)$. Når det gjelder andre arytmiformer, har en randomisert studie med 160 pasienter vist at to kapsler med omega-3-fettsyrer (Omacor) før bypassoperasjon ga signifikant redusert forekomst av atrieflimmer i intervensjonsgruppen $\mathrm{i}$ forhold til kontrollgruppen. Postoperativ atrieflimmer oppsto hos 27 pasienter i kontrollgruppen og hos 12 pasienter i Omacor-gruppen $(p=0,017)(32)$.

En ny metaanalyse vedrørende bruk av omega-3-fettsyrer hos pasienter med implanterbar kardioverterdefibrillator viste ikke effekt angående utløsning av elektrisk støt eller hjertedød (33). Det er postulert at dette kan skyldes at det hos postinfarktpasienter hovedsakelig er iskemi som er utløsende arytmiårsak, mens pasienter med implanterbar kardioverterdefibrillator på forhånd oftest er revaskulisert og har reentryarytmier primært utløst av arrvev (34).

\section{Metaanalyser}

Basert på kohortsstudier og randomiserte studier konkluderte Hooper og medarbeidere i 2006 med at omega-3-fettsyrer ikke har klar effekt på totalmortalitet eller kombinerte kardiovaskulære endepunkter (35). Analysen er blitt kritisert fordi den bygger på et heterogent pasientmateriale og fordi den største studien var en primærprofylaktisk norsk undersøkelse fra 1960-årene hvor det ble anvendt alfalinolensyre fremfor DHA/EPA (36). En annen studie basert på 11 kliniske forsøk viste at tilskudd av omega-3-fettsyrer eller økt inntak av disse i kostholdet ga en statistisk signifikant reduksjon i relativ risiko på $30 \%$ for død på grunn av hjerteinfarkt og for plutselig død (37). Henholdsvis $6,7 \%$ i kontrollgruppen og 6,2\% i intervensjonsgruppen døde av hjerteinfarkt eller fikk en plutselig død (36).

En ny metaanalyse, basert på randomiserte undersøkelser der pasientene fra GISSI- og JELIS-studiene utgjør $92 \%$ av pasientmaterialet, viser en statistisk signifikant $20 \%$ reduksjon i hjertedødelighet ved bruk av omega-3-fettsyrer, men det var ingen effekt på totaldødelighet eller arytmi (38). 2,7\% i kontrollgruppen døde av hjertesykdom, tallet $\mathrm{i}$ intervensjonsgruppen var $2,2 \%$ (38). Lav hjertedødelighet og stort fiskeforbruk i 
Tabell 1 Sammenhengen mellom daglig inntak av fiskeprodukter og det man får i seg av EPA/ DHA. Modifisert fra data fra det danske fødevareinstituttet, Danmarks Tekniske Universitet (51)

\begin{tabular}{lccc} 
& 500 mg EPA/DHA & $1 \mathrm{~g}$ EPA/DHA & $4 \mathrm{~g}$ EPA/DHA \\
\hline Laks, rå (g) & 20,4 & 40,8 & 163,3 \\
\hline Torsk, rå (g) & 217,4 & 434,8 & 1739,1 \\
Makrell, i tomat (g) & 15,9 & 31,8 & 127,4 \\
Tunfisk, i olje (g) & 171,8 & 343,6 & 1374,6
\end{tabular}

Japan kan være medvirkende forklaringer på funnene i denne metaanalysen og på resultatulikhetene i GISSI- og JELIS-studiene.

\section{Omega-3-indeksen som risikofaktor} Indeksen beregnes som mengden EPA og DHA i røde blodcellemembraner, uttrykt som prosent av totale fettsyrer, og anses som et surrogatmål for hjertets omega-3-innhold. Indeksen anses å fylle mange av kravene til en risikofaktor. Disse omfatter blant annet epidemiologisk evidens, plausibilitet, reproduserbarhet og uavhengighet $\mathrm{i}$ forhold til andre risikofaktorer (39). En omega-3indeks på mer enn $7-8 \%$ er assosiert med omkring $90 \%$ mindre risiko for plutselig hjertedød enn en indeks på under $4 \%$ (39, $40)$. I et materiale hadde $44 \%$ av voksne som ikke tok tilskudd av omega-3, en indeksverdi på under 4\% (41). Hos 768 pasienter med akutt koronarsyndrom som ble sammenliknet med en kontrollgruppe, var oddsratio for sykdom gradvis økende med fallende omega-3-indeks (42).

I en ny norsk studie har man undersøkt sammenhengen mellom omega-3-indeks og ventrikkelflimmer $\mathrm{i}$ forløpet av et akutt hjerteinfarkt. Av 265 pasienter med akutt myokardinfarkt fikk ti ventrikkelflimmer innen seks timer. Etter justering for andre risikofaktorer viste det seg at en økning på $1 \%$ i omega-3-indeksen ga en risikoreduksjon på $48 \%$ for ventrikkelflimmer (43). Median verdi for omega-3-indeksen var 4,88\% i ventrikkelflimmergruppen og $6,08 \%$ i kontrollgruppen (43). Resultatet var statistisk signifikant, men på grunn av få pasienter med ventrikkelflimmer er det behov for bekreftende studier.

Den samme studiegruppen har vurdert om omega-3-indeksen kan predikere totaldødelighet, hjertedødelighet eller hjerteinfarkt etter gjennomgått akutt koronarsyndrom. 460 pasienter ble inkludert og fulgt opp i to år (44). Det var ikke signifikante forskjeller i hendelser mellom pasientene i laveste og pasientene i høyeste kvartil av indeksen. Én mulig forklaring er at pasientpopulasjonen hadde et høyt inntak av omega-3-fettsyrer, med medianverdi for indeksen på $6,42 \%$. Når det gjelder plutselig død, var antallet dødsfall så lite at statistisk analyse var uaktuelt (44).

\section{Status og anbefalinger}

Ifølge de nordiske ernæringsanbefalingene bør $0,5 \%$ av det daglige energiinntaket kommer fra omega-3-fettsyrer (45). Datagrunnlaget for fiskeforbruket i Norge er usikkert. Ut fra Norkost-undersøkelsen fra 1997 antas det at det daglige fiskeinntaket $i$ Norge tilsvarer under halvparten av anbefalt omega-3-fettsyreinntak (46). Det gjennomsnittlige fiskeinntaket er $65 \mathrm{~g}$ per dag, ifølge Helsedirektoratet, men kun omkring $30 \%$ er i form av fet fisk og fiskepålegg. Direktoratet anser dette som lavere enn ønskelig (47) Det vil være betydelige individuelle variasjoner i omega-3-fettsyreinntaket, og det er vist forskjeller knyttet til alder, sosial klasse og geografisk lokalisering $(46,48)$. I USA er omega-3-fettsyreinntaket fra EPH/DHA anslått til omkring $200 \mathrm{mg}$ daglig (7). Tilsvarende i Japan er $0,8-1,5 \mathrm{~g}$ om dagen (49).

Verdens helseorganisasjons anbefaling er at $1-2 \%$ av det daglige energiinntaket skal komme fra omega-3-fettsyrer (50). American Heart Association anbefaler ulike mengder til ulike pasientkategorier, slik det fremgår i ramme 1 (7). For at man skal få i seg $500 \mathrm{mg}$, $1 \mathrm{~g}$ eller $4 \mathrm{~g}$ DHA/EPA kun via kostholdet, må det daglige inntaket av maritime produkter være som anført i tabell 1 (51). Det bør vanligvis være mulig å oppnå tilstrekkelige nivåer av omega-3-fettsyrer uten å ta tilskudd. Unntaket er ved alvorlig hypertriglyseridemi, da høykonsentrert tilskudd anbefales. I oppdrett av laks brukes i økende grad vegetabilsk fôr. Dette kan gi lavere innhold av omega-3fettsyrer i laksen og dermed redusert inntak av omega-3-fettsyrer i kostholdet (52).

\section{Konklusjon}

Observasjonelle og randomiserte studier indikerer at et moderat inntak av fet fisk eller omega-3-tilskudd tilsvarende to måltider $\mathrm{i}$ uken gir redusert risiko for hjertesykdom og død. Det er holdepunkter for å anta at det også er gunstige effekter når det gjelder arytmier og plutselig hjertedød, men det trengs mer forskning for å avklare omega-3-fettsyrenes rolle her.

GISSI-HF-studien har aktualisert spørsmålet om hvorvidt hjertesviktpasienter bør få tilbud om reseptbelagte omega-3-fettsyrer i tillegg til standard hjertesviktbehandling. En reduksjon i relativ risiko for totaldødelighet på $9 \%$, som vist i GISSI-HF, må anses som betydningsfull (22).

\section{Litteratur}

. GISSI-Prevenzione Investigators. Dietary Supplementation with $\mathrm{n}-3$ polyunsaturated fatty acids and vitamin E after myocardial infarction; results of the GISSI-Prevenzione Trial. Lancet 1999: 354 4447-55.

2. Verschuren WM, Jacobs D, Blomberg BP et al. Serum total cholesterol and long-term coronary heart disease mortality in different cultures. Twenty-five year follow up of the seven countries study. JAMA 1995; 274: 131-6.

3. Leaf A, Albert CM, Josephson M et al. Prevention of fatal arrhythmias in high-risk subjects by fishoil n-3 fatty acid intake. Circulation 2005; 112 2762-8.

4. Burr ML, Gilbert JF, Holiday RM et al. Effects of changes in fat, fish and fibre intakes on death and myocardial infarctions: diet and reinfarction trial (DART). Lancet 1989: 2: 757-61.

5. Daviglus ML, Stamler J, Orienca AJ et al. Fish con sumption and the 30-year risk of fatal myocardial infarction. N Engl J Med 1997; 2336: 1046-53.

6. Mozaffarian D, Rimm EB. Fish intake, contaminants, and human health: evaluating the risks and the benefits. JAMA 2006; 296: 1885-9.

7. Kris-Etherton PM, Harris WS, Lawrence JA et al. Fish consumption, fish oil, omega- 3 fatty acids, and cardiovascular disease. Circulation 2002; 106 2747-57.

8. Grundt H, Nilsen DW. n-3 fatty acids and cardiovascular disease. Haematologica 2008; 93 : $807-12$.

9. Harris WS, Miller M, Tighe AP et al. Omega-3 fatty acids and coronary heart disease risk: clinical and mechanistic perspectives. Atherosclerosis 2008; 197: $12-24$

10. Johansen 0 . Studies on coronary angioplasty restenosis and very long chain $n-3$ fatty acids. Oslo: Oslo universitetssykehus, Ullevål, Universitetet i Oslo, 1999

11. Webb NR. Getting to the core of atherosclerosis. Nat Med 2008: 14: 1015-6.

12. Huikuri H, Castellanos A, Myerburg RJ. Sudden death due to cardiac arrhythmias. N Engl J Med 2001; 345: 1473-82

13. Græsdal, A. Hovland A, Bjørbæk E. Aferesebehandling ved alvorlig hyperkolesterolemi. Tidsskr Nor Lægeforen 2004; 124: 1085-7.

14. Domanski MJ. Primary prevention of coronary artery disease. N Engl J Med 2007; 357: 1543-5.

15. Stein D, Glass K, Witztum JL et al. Evidence mandating earlier and more aggressive treatment of hypercholesterolemia. Circulation 2008; 118 $672-7$

16. Lee KW, Lip GY. The role of omega-3-fatty acids in the secondary prevention of cardiovascular disease. Q J Med 2003; 96: 465-80.

17. Jacobson TA. Role of $n-3$ fatty acids in the treatment of hypertriglyceridemia and cardiovascular disease. Am J Clin Nutr 2008; 87: 1981-90.

18. Mozaffarian D. Fish and n-3 fatty acids for the prevention of fatal coronary heart disease and sudden cardiac death. Am J Clin Nutr 2008; 87: 1991S-6S

19. Takei H, Strong JP, Yutani $C$ et al. Comparison of coronary and aortic sclerosis in youth from Japan and the USA. Atherosclerosis 2005; 180: 171-9.

20. Sekikawa A, Curb D, Ueshima H et al. Marinederived $n-3$ fatty acids and atherosclerosis in Japanese, Japanese-American, and white men. J Am Coll Cardiol 2008. 52: 417-24.

21. Yokoyama M, Origasa H, Matsuzaki M et al. Effects of eicosapentaenoic acid on major coronary events in hypercholesterolaemic patients (JELIS): a randomised open-label, blinded endpoint analysis. Lancet 2007: 369: 1090-8.

22. GISSI-HF investigators. Effect of $n-3$ polyunsaturated fatty acids in patients with chronic heart failure (the GISSI-HF trial). Lancet 2008; 372 1223-30.

23. Burr ML, Ashfield-Watt PAL, Dunstad FS et al. Lack of benefit of dietary advice to men with angina: results of a controlled trial. Eur J Clin Nutr 2003; 57: 193-200.

24. Landmark K, Aursnes I, Reikvam A et al. Omega3 -fettsyrer er fortsatt gunstig ved hjertesykdom. Tidsskr Nor Lægeforen 2007; 127: 202-3.

25. www.medscape.com/viewarticle/590625 (14.5.2009). 
26. Hjerkinn EM, Abdelnoor M, Breivik L et al. Effect of diet or very long chain omega-3 fatty acids on progression of atherosclerosis, evaluated by carotis plaque, intima-media thickness and by pulse wave propagation in elderly men with hypercholesterolaemia. Eur J Cardiovasc Prev Rehabil 2006; 13: 325-33.

27. Kannel WB, Kannel C, Paffenbarger RS et al. Heartrate and cardiovascular mortality: the Framingham study. Am Heart J 1987: 113: 1489-94.

28. O'Keefe JH, Abuissa H, Sastre A et al. Effects of omega-3 fatty acids on resting heart rate, heart rate recovery after exercise, and heart rate variability in men with healed myocardial infarctions and depressed ejection fractions. Am J Cardiol 2006; 97: 1127-30.

29. Mozaffarian D, Geelen A, Brouwer IA et al. Effects of fish oil on heart rate in humans: a meta-analysis of randomized controlled trials. Circulation 2005; 112: $1945-52$

30. Leaf A, Kang JX, Xiao YF et al. Clinical prevention of sudden cardiac death by $n-3$ polyunsaturated fatty acids and mechanism of prevention of arrhythmias by $\mathrm{n}-3$ fish oils. Circulation 2003; 107: $2646-52$

31. McLennan PL. Myocardial membrane fatty acids and the antiarrhythmic actions of dietary fish in animal models. Lipids 2001: 36 (suppl): S111-4.

32. Calo L, Bianconi L, Colivicci F et al. N-fatty acids for the prevention of atrial fibrillation after coronary bypass surgery: a randomized controlled trial. J Am Coll Cardiol 2005; 45: 1723-8.

33. Jenkins D, Josse AR, Beyene J et al. Fish-oil supplementation in patients with implantable cardioverter defibrillators: a meta-analysis. CMAJ 2008; 178: 157-64.
34. Albert CM. Omega-3 fatty acids and ventricular arrhythmias: nothing is simple. Am Heart J 2008; 155: 967-70.

35. Hooper L, Thompson RL, Harrison RA et al. Risks and benefits of omega 3 fats for mortality, cardiovascular disease, and cancer: a systematic review. BMJ 2006; 332: 752-5.

36. Natvig H, Borchgrevink CF, Dedichen J et al. A controlled trial of the effects of linolenic acid on incidence of coronary disease. The Norwegian vegetable oil experiment of 1965-66. Scand J Clin Lab Invest Suppl 1968; 105: 1-20.

37. Bucher HC, Hengstler P, Schindler $C$ et al. N-3 polyunsaturated fatty acids in coronary heart disease: a meta-analysis of randomized controlled trials. Am J Med 2002; 12: 298-304.

38. Leon $H$, Shibata M, Sivakumaran $S$ et al. Effect of fish oil on arrhythmias and mortality: systematic review. BMJ 2008; 337: a2931.

39. Harris WS, Von Schacky C. The Omega-3 Index: a new risk factor for death from coronary heart disease? Prev Med 2004; 39: 212-20.

40. Harris WS. Omega-3 fatty acids and cardiovascular disease: omega- 3 index as a new risk factor. Phar macol Res 2007; 55: 217-23.

41. Sands SA, Reid KJ, Windsor SL et al. The impact of age, body mass index, and fish intake on the EPA and DHA content of human erythrocytes. Lipids 2005; 40: 343-7.

42. Block RC, Harris WS, Reid KJ et al. EPA and DHA in blood cell membranes from acute coronary syndrome patients and controls. Atherosclerosis 2008; 197: 821-8

43. Aarsetøy H, Pønitz V, Nilsen OB et al. Low levels of cellular omega- 3 increase the risk of ventricular fibrillation during the acute ischaemic phase of myocardial infarction. Resuscitation 2008. 78 : $258-64$.

44. Aarsetøy H, Pønitz V, Grundt H et al. (n-3) fatty acid content of red blood cells does not predict risk of future cardiovascular events following an acute coronary syndrome. J Nutr 2009; 139: 507-13.

45. Nordic Nutrition Recommendations 2004 - integrating nutrition and physical activity. Nord 2004 : 13. København: Nordisk ministerråd, 2005.

46. Norkost. www. helsedirektoratet.no/ernaering/ kostholdetundersokelser/norkost (21.1.2009).

47. Fisk. www. helsedirektoratet.no/vp/template/ver1$0 /$ print.jsp?articleld $=66502 \&$ sectionld $=853$ (22.3.2009).

48. Johansson LRK, Solvoll K, Bjørneboe G-E et al. Intake of very-long-chain $n-3$ fatty acids related to social status and lifestyle. Eur J Clin Nutr 1998; 52 $716-21$.

49. Harris W. Omega- 3 fatty acids: the «Japanese» factor? J Am Coll Cardiol 2008; 52: 425-7.

50. Diet, nutrition and the prevention of chronic diseases. Report of a joint WHO/FAO expert consultation. WHO Technical Report Series -916. Genève: WHO/FAO, 2003. www.who.int/hpr/NPH/docs/ who_fao_expert_report.pdf (21.1.2009).

51. DTU Fødevareinstituttet. Fødevaredatabanken. www.foodcomp.dk/fvdb default.asp [21.1.2009].

52. Seierstad SL, Seljeflot I, Johansen 0 et al. Dietary intake of differently fed salmon; the influence on markers of human atherosclerosis. Eur J Clin Invest 2005; 35: 52-9.

Manuskriptet ble mottatt 31.10. 2008 og godkjent 14.5. 2009. Medisinsk redaktør Trine B. Haugen. 